\title{
Growth and Yields of 'Arbequina' High-Density Planting Systems in Three Different Olive Growing Areas in Italy
}

\author{
T. Caruso, G. Campisi and F.P. Marra \\ Dipartimento Scienze Agrarie e Forestali \\ University of Palermo \\ Italy \\ S. Camposeo and G.A. Vivaldi \\ Dipartimento di Scienze Agro-Ambientali e Territoriali \\ University of Bari Aldo Moro \\ Italy \\ P. Proietti and L. Nasini \\ Dipartimento di Scienze Agrarie e Ambientali \\ University of Perugia \\ Italy
}

Keywords: Olea europaea, mechanical harvesting, olive oil chemical and sensory characteristics

\begin{abstract}
The sustainability of the traditional olive-growing sector in EU countries characterised by high production costs and a low selling price for the oil - was mainly determined by EU subsidies available for the sector. With the opening of the "free trade" area by the Barcellona Declaration of 1995 and a cut in EU subsidies in 2014, crucial changes in the sector are now needed. In order to increase the competitiveness of EU olive production, attention should be given to new highyielding and mechanized cultivation systems. In the 1990s, Spain introduced new high-density planting systems $(1,200-2,000$ trees/ha) using three low-vigour and early-fruiting cultivars ('Arbequina', 'Arbosana' and 'Koroneiki'). Italian olive production lies in a geographical area that stretches for about $6^{\circ}$ in latitude $\left(37-43^{\circ}\right.$ latitude $N$ ) and in the band of altitude which ranges from sea level to $400 \mathrm{~m}$ a.s.l. Studies on the ecophysiology of woody plants show the importance of adapting the planting system to the climate of the cultivation site, particularly for high-density groves. The evaluation of cultivars suitable for high-density systems, based on their vegetative characteristics, branching and fruiting, together with an analysis of product quality, may contribute significantly to the development and diffusion of new crop growing systems. To achieve this aim, joint research was carried out by three different research units operating in the three main olive-growing regions of Italy (Sicily, Apulia and Umbria). This paper illustrates the first results (2010 and 2011) obtained by the PRIN Project on "Biological processes and environmental factors affecting the vegetative growth, fruiting and oil quality control in a high density olive (Olea europaea L.) planting system".
\end{abstract}

\section{INTRODUCTION}

Data from the International Olive Council (IOC) indicates that world olive oil production has increased at the same rate as consumption, reaching approximately 2.8 million $t$ in 2010. Spain's production capacity has grown considerably (approximately 1.2 million $\mathrm{t}$ ) and some southern Mediterranean countries, such as Tunisia and Morocco, eastern Mediterranean countries, such as Turkey and Syria, and a number of countries in the Southern Hemisphere (Chile, Australia, Argentina, etc.) have recently taken on a more prominent role in the world market. Production from these 'emerging' olive producing countries, after satisfying their domestic demand, will, undoubtedly, be channelled into the international market in the medium- and long-term, thereby increasing the level of 
competition in the sector. The progressive contraction in Italy's olive oil market share is the result of a number of reasons, however, higher prices due to greater production costs compared to other countries have played an important role. Until recently, economic feasibility in the olive growing sector in EU countries was determined by subsidies (Godini et al., 2011). As a result of the opening of the free-trade area by the Barcelona Declaration of 1995 and the EU cut in subsidies, which are expected to come into force in 2014, reorganization of the whole sector is essential if we have to ensure that Italy's olive growing sector does not become merely picturesque or carry out an environmental protection function only (Proietti and Tombesi, 1996; Camposeo and Godini, 2010).

In the 1990s, a new planting system was developed in Spain, known as super highdensity, due to the high tree planting density $(1,200-2,000$ trees/ha), which used mostly 3 low vigour and early-fruiting cultivars ('Arbequina', 'Arbosana' and 'Koroneiki'). In this system, trees are grown around a central axis with a rectangular layout (3.5-4x 1.2-1.6 m), creating fruiting walls which allow for continuous mechanical harvesting using straddle harvesters, commonly found in the wine-growing industry (Camposeo et al., 2008). Since the first hectares were trialled in Spain in 1994, the high-density system has spread throughout a number of countries and is employed in about 100,000 ha all over the world (Mateu et al., 2008). In Italy, the high-density system was introduced in 2001 and today there are about 1,000 ha using the system (Camposeo, pers. commun.). Economic feasibility requires that the high-density olive groves bear high, constant levels of fruit for at least 20 years (Tous et al., 2011). However, a number of technical hitches regarding the cropping management of this system starts to be solved, especially as far as canopy functionality is concerned in relation to environmental factors and cultivation practices (Camposeo and Vivaldi, 2011; Proietti et al., 2012; Strippoli et al., 2013; Vivaldi et al., 2013).

Most of Italy's olive groves spreads out in a vast area which stretches for approximately $6^{\circ}$ in latitude $\left(37^{\circ}-43^{\circ}\right.$ latitude $\left.N\right)$ and at an altitude which ranges from sea level to $400 \mathrm{~m}$ a.s.l. It would, therefore, be of great interest to gain a clear idea of how easily the high-density system adapts to varying environmental conditions. Joint research carried out in three different research centres from 3 key olive producing regions in Italy can be seen as an initial step towards achieving this, and the results of the research are illustrated below.

\section{MATERIALS AND METHODS}

The same methods were used to carry out this research work on 3 different experimental olive groves in 2010 and 2011; the main characteristics of the experimental sites are shown in Table 1. Each of the test sites used 3 blocks of 10 trees of the cultivar 'Arbequina', chosen according to uniformity of trunk diameter, canopy volume and tree height. In all sites, tree height was $2.5-3 \mathrm{~m}$, which is the maximum height at which the straddling harvesters can operate. All the olive groves were irrigated and in Sicily, where water requirements are greatest, seasonal volumes of irrigation were maximum (approx. $2000 \mathrm{~m}^{3} / \mathrm{ha}$ ).

In order to determine the best time to harvest, the evolution of the fruit pigmentation was determined using the Jaén index on a scale of 0 (dark green epicarp) to 7 (completely pigmented epicarp and mesocarp). Harvesting was carried out when the olives reached a Jaén index score of 2.5-3 (Camposeo et al., 2013). Yield and trunk diameter at $40 \mathrm{~cm}$ from the base were determined on 10 plants per block and, successively, the trunk cross sectional area (TCSA), yield per hectare and production efficiency (PE - expressed as a ratio of tree yield to TCSA) were calculated. Production data relative to the two years of research were then added to those of previous years in order to give a broader idea of yield in the early years. In each of the experimental groves three samples of fruit were taken from the harvested olives and the oil was extracted from each sample in order to carry out chemical and sensory analyses according to standard methods (Reg. EU N. 61/2011). 


\section{RESULTS AND DISCUSSION}

\section{Growth and Yield}

In all three olive groves fruit production began during the $3^{\text {rd }}$ year following planting (Fig. 1A). However, whilst in Apulia and Sicily average yields were around $2.5 \mathrm{~kg} /$ tree, in Umbria fruit yields were found to be rather low $(0.2 \mathrm{~kg} /$ tree $)$. During the $4^{\text {th }}$ year, production increased considerably with yields of $5.6 \mathrm{~kg} /$ tree in Apulia $(+65 \%)$, $4.6 \mathrm{~kg}$ in Sicily $(+42 \%)$ and $2.2 \mathrm{~kg}$ in Umbria $(+65 \%)$. The following year an increase in yields was recorded on the trees in the study in Umbria $(5.0 \mathrm{~kg} / \mathrm{tree})$, whereas yields remained more or less unaltered at the other two sites (approx. $5.5 \mathrm{~kg} /$ tree). Greatest yields $\left(7 \mathrm{~kg} /\right.$ tree) were produced in Sicily and Apulia during the $6^{\text {th }}$ year, whereas a fall in production was recorded in the olive groves in Umbria. In Sicily, where the oldest of the three experimental groves was located, yields were found to be approximately $6.7 \mathrm{~kg} /$ tree in the $8^{\text {th }}$ year, a level which did not differ greatly from yields obtained from the previous year. Despite the difference in planting density between the Sicilian grove (1,905 trees/ha) and that of Apulia (1,666 trees/ha), yields were reasonably similar (Fig. 1B); yields in Umbria, however, were decidedly lower. Nevertheless, yields obtained were consistent with results found in literature for super high-density planting systems using 'Arbequina' of the same age (Camposeo and Godini, 2010; Tous et al., 2011). TCSA results for the Sicilian trees for both years of the study were found to be greater than those for the trees in Apulia and Umbria, this due to the fact that the trees in the Sicilian site were older. In the Umbria site, despite the fact that the grove was the same age as the Apulia one, the trees were found to have lower TCSA values (Fig. 2A), due to a shorter growing season and a lower vegetative growth potential. Production efficiency (PE) for both years was found to be between $0.17-0.19 \mathrm{~kg} / \mathrm{cm}^{2}$ in Apulia and in Sicily (Fig. 2B), whilst in Umbria figures ranged from $0.22 \mathrm{~kg} / \mathrm{cm}^{2}$ in 2010 to $0.13 \mathrm{~kg} / \mathrm{cm}^{2}$ in 2011 .

\section{Olive Ripening and Harvesting}

The pre-established ripening index to proceed with harvesting (Jaén index 2.5-3), was reached in Sicily in 2010 towards the end of October (Table 2), in Apulia during the first 10 days of November and towards the end of October/beginning of November in Umbria. In 2011, the harvesting period in all three sites was during the first 10 days of November.

\section{Oil Quality}

During both of the study years, the olive oils obtained fell within the classification of extra virgin. Oleic acid levels were found to be higher in the oils produced in Umbria, where levels peaked at 76\% in 2010, compared to levels produced in Apulia and in Sicily which, in 2011 , were $64 \%$ (Table 2). In the more southerly study sites, the lower oleic acid content in the oils was coupled with higher saturated and polyunsaturated fatty acids content. The linoleic acid content ranged between 7\% (Umbria) and 13\% (Sicily) and palmitic acid ranged between 12\% (Umbria) and 20\% (Apulia). The ratio between saturated and unsaturated fatty acids was found to be higher in the Umbria oils (5:1 in $2010,5.7: 1$ in 2011) than in the oils from the two southern Italian sites, which varied between 3.5 (Apulia 2011) and 4.7 (Apulia 2010).

Differences in the fatty acid composition of the oils was expected, as it is known that as we move north, oleic acid levels increase and, conversely, there is a reduction in the linoleic content (Inglese et al., 2009). In Apulia in 2011, the palmitic acid content reached the maximum limit $(20 \%)$ as fixed by the Commission Regulation (EU) No. 61/2011. Most probably the seasonal weather trends in Apulia did not favour normal lipogenesis processes but promoted the creation of saturated fatty acids rather than unsaturated ones. Obviously this aspect deserves further attention, as higher levels of palmitic acid would exclude the oil from being categorized as extra virgin.

Regarding the nutraceutical aspects, the oils produced in Sicily and Umbria had a 
total polyphenol content (TPC) which was higher than that of the Apulia oils (Table 2). In 2010, the TPC (Table 2) ranged between $231 \mathrm{ppm}$ (Apulia) and $524 \mathrm{ppm}$ (Umbria); in 2011, the oil with the highest TPC was produced in Sicily (428 ppm). In general, the oils produced in all 3 sites were found to be well-balanced and of medium-fruity intensity (Table 3). Compared to oils produced in the hotter areas of Apulia and Sicily, the oil produced in Umbria was slightly bitterer (2.5-3), spicier (3-3.5) and with greater fruity intensity (3.5). Overall, results of the chemical and sensory analysis were similar to those from other studies carried out in Italy (Camposeo et al., 2006, 2010; Mersi, 2008).

\section{CONCLUSIONS}

In spite of the marked environmental conditions among the 3 Italian sites, the overall results of this study showed that the cultivar 'Arbequina' grown in high-density planting system gave good production results, in line with the available literature (Vossen, 2007; Godini et al., 2011). The production levels of the groves were slightly higher than those obtained by intensive irrigated systems (300-400 trees/ha; Vossen, 2007; De Gennaro et al., 2012), but much higher than traditional ones (Barone et al., 1986). During this study, yields obtained were comparable to those found in the first high-density planting system, established in Spain, which is currently almost 20 years old (Tous et al., 2011). However, it remains to be understood whether in the three Italian experimental groves current production levels will continue in the future.

As far as the qualitative aspects are concerned, chemical and organoleptic results of 'Arbequina' oil in all 3 Italian sites fell into the variation interval reported for the same cultivar in Spain, where 'Arbequina' represents 3\% of the Spanish olive area within two important P.D.O. (Tous et al., 1997, 1999; Uceda et al., 1999). On average, the polyphenol content ensures that the 'Arbequina' oils are classified as well-balanced sweet oils, similar to some much better known Italian native cultivars, such as the awardwinning 'Tonda Iblea' in Sicilia and 'Cima di Bitonto' in Apulia.

In conclusion, it is reasonable to suppose that in Italy, as in other olive growing countries, two types of olive cultivation could co-exist: one which is historically linked to typical olive oil production and landscape conservation as well as to the rich heritage of genetic resources and, therefore, to traditional products, and one which is based on cultivation systems which can cut production costs and compete on the international extra virgin olive oil market.

\section{Literature Cited}

Barone, E., Caruso, T., Di Marco, L. and Inglese, P. 1986. Osservazioni preliminari sul comportamento bio-agronomico di 14 cultivar di olivo da tavola nella Sicilia occidentale. Riv. Frutt. 8:55-63.

Camposeo, S., Cantore, A., Barbieri, N. and Godini, A. 2006. 'Arbequina' e 'Arbosana' alla prova della qualità. Olivo \& Olio 9(11-12):12-14.

Camposeo, S., Ferrara, G., Palasciano, M. and Godini, A. 2008. Varietal behaviour according to the superintensive oliveculture training system. Acta Hort. 791:271-274.

Camposeo, S. and Godini, A. 2010. Preliminary observations the performance of 13 varieties according to the super high density oliveculture training system in Apulia (southern Italy). Adv. Hort. Sci. 24(1):16-20.

Camposeo, S., Vivaldi, G.A., Gallotta, A., Barbieri, N. and Godini, A. 2010. Valutazione chimica e sensoriale degli oli di alcune cv di olivo allevate in Puglia col modello superintensivo. Riv. Frutt. 72(6):80-83.

Camposeo, S. and Vivaldi, G.A. 2011. Short-term effects of de-oiled olive pomace mulching application on a young super high-density olive orchard. Sci. Hort. 129:613621.

Camposeo, S., Vivaldi, G.A. and Gattullo, C.E. 2013. Ripening indices and harvesting times of different olive cultivars for continuous harvest. Sci. Hort. 151:1-10.

De Gennaro, B., Noarnicola, B., Roselli, L. and Tasselli, G. 2012. Innovative olivegrowing models: an environmental and economic assessment. J. Clean. Prod. 28:70- 
80.

Godini, A., Vivaldi, G.A. and Camposeo, S. 2011. Olive cultivars field-tested in superhigh-density system in southern Italy. Calif. Agri. 65(1):39-40.

Inglese, P., Famiani, F. and Servili, M. 2009. I fattori di variabilità genetici, ambientali e colturali della composizione dell'olio di oliva. Italus Hortus 16(4):67-81.

Mateu, J.C., Garcia, R.X. and Peña, J.M.L. 2008. Evoluzione della superficie piantata a olivi con il sistema superintensivo o a cespuglio nel mondo. Olint. 15:1-7

Mersi, A. 2008. Superintensivi made in Italy. Un confronto sensoriale. Olivo \& Olio 11(2):36-41.

Proietti, P. and Tombesi, A. 1996. Translocation of assimilates and source-sink influences on productive characteristics of the olive tree. Adv. Hort. Science 10:11-14.

Proietti, P., Nasini, L. and Ilarioni, L. 2012. Photosynthetic behaviour of Spanish Arbequina and Italian Maurino olive (Olea europaea L.) cultivars under superintensive grove conditions. Photosynthetica 50:239-246.

Strippoli, G., Vivaldi, G.A., Camposeo, S. and Contò, F. 2013. Sprouts seasonal elongation of two olive cultivars in a high-density orchard. Agric. Sci. 4(8):376-381.

Tous, J. 2011. Olive production systems and mechanization. Acta Hort. 924:169-184.

Tous, J., Romero, A., Plana, J., Guerrero, L., Diaz, I. and Hermoso, J.F. 1997. Chemical and sensory characteristics of Arbequina olive oil obtained in different growing areas of Spain. Grasas y Aceites 48(6):415-424.

Tous, J., Romero, A. and Diaz, I. 1999. Fruit and oil characteristics of five Spanish olive cultivars. Acta Hort. 474:639-642.

Uceda, M., Hermoso, M., Garcia-Ortiz, A., Jimenez, A. and Beltran, G. 1999. Intraspecific variation of oil contents and the characteristics of oil in olive cultivars. Acta Hort. 474:659-662.

Vivaldi, G.A., Strippoli, G. and Camposeo, S. 2013. Ecophysiological response to irrigation of two olive cultivars grown in a high-density orchard. Agric. Sci. 4(8A):1620.

Vossen, P. 2007. Olive oil: history, production, and characteristics of the world's classic oils. Hort. Sci. 42(5):1093-1100. 


\section{Tables}

Table 1. Main characteristics of the experimental olive groves located in three different olive growing areas in Italy.

\begin{tabular}{lcccc}
\hline & $\begin{array}{c}\text { Geographical coordinates } \\
\text { and altitude (m a.s.1.) }\end{array}$ & $\begin{array}{c}\text { Planting } \\
\text { year }\end{array}$ & $\begin{array}{c}\text { Tree space } \\
(\mathrm{m})\end{array}$ & $\begin{array}{c}\text { Planting density } \\
\left(\text { tree ha }^{-1}\right)\end{array}$ \\
\hline Sicily & $\begin{array}{c}37^{\circ} 46^{\prime} \mathrm{N} ; 12^{\circ} 30^{\prime} \mathrm{E} \\
160 \mathrm{~m}\end{array}$ & 2005 & $3.5 \times 1.5$ & 1905 \\
Apulia & $\begin{array}{c}41^{\circ} 01^{\prime} \mathrm{N} ; 16^{\circ} 45^{\prime} \mathrm{E} \\
110 \mathrm{~m}\end{array}$ & 2006 & $4.0 \times 1.5$ & 1666 \\
Umbria & $\begin{array}{c}42^{\circ} 57^{\prime} \mathrm{N} ; 12^{\circ} 25^{\prime} \mathrm{E} \\
350 \mathrm{~m}\end{array}$ & 2006 & $4.0 \times 1.5$ & 1666 \\
\hline
\end{tabular}

Table 2. Harvest date and olive oil chemical composition of 'Arbequina' in super high density planting systems, in three different olive growing areas in Italy.

\begin{tabular}{lcccccc}
\hline & $\begin{array}{c}\text { Harvest } \\
\text { date }\end{array}$ & $\begin{array}{c}\text { Total } \\
\text { polyphenol } \\
(\mathrm{ppm})\end{array}$ & $\begin{array}{c}\text { Oleic } \\
\text { acid } \\
(\%)\end{array}$ & $\begin{array}{c}\text { Linoleic } \\
\text { acid } \\
(\%)\end{array}$ & $\begin{array}{c}\text { Palmitic } \\
\text { acid } \\
(\%)\end{array}$ & $\begin{array}{c}\text { Unsaturated/ } \\
\text { saturated } \\
\text { ratio }\end{array}$ \\
\hline \multirow{2}{*}{ Sicily } & 26 Oct. 2010 & 478 & 64 & 13 & 17 & 4.0 \\
& 9 Nov. 2011 & 428 & 64 & 11 & 18 & 4.0 \\
\hline \multirow{2}{*}{ Apulia } & 15 Nov. 2010 & 231 & 68 & 10 & 15 & 4.7 \\
& 9 Nov. 2011 & 290 & 64 & 10 & 21 & 3.5 \\
\hline \multirow{2}{*}{ Umbria } & 8 Nov. 2010 & 524 & 76 & 7 & 12 & 5.7 \\
& 9 Nov. 2011 & 390 & 71 & 9 & 15 & 3.0 \\
\hline
\end{tabular}

Table 3. Harvest date and olive oil sensory characteristics of 'Arbequina' in super high density planting systems, in three different olive growing areas in Italy.

\begin{tabular}{lcccc}
\hline Harvest date & $\begin{array}{c}\text { Fruity } \\
(0-5)^{*}\end{array}$ & $\begin{array}{c}\text { Bitter } \\
(0-5)^{*}\end{array}$ & $\begin{array}{c}\text { Pungency } \\
(0-5)^{*}\end{array}$ \\
\hline \multirow{2}{*}{ Sicily } & 26 Oct. 2010 & 3.5 & 2.0 & 2.0 \\
& 9 Nov. 2011 & 2.5 & 2.0 & 2.5 \\
\hline \multirow{2}{*}{ Apulia } & 15 Nov. 2010 & 3.5 & 2.0 & 2.0 \\
& 9 Nov. 2011 & 2.2 & 2.0 & 2.0 \\
\hline \multirow{2}{*}{ Umbria } & 8 Nov. 2010 & 3.5 & 2.5 & 3.0 \\
& 9 Nov. 2011 & 3.5 & 3.0 & 3.5 \\
\hline
\end{tabular}




\section{Figures}
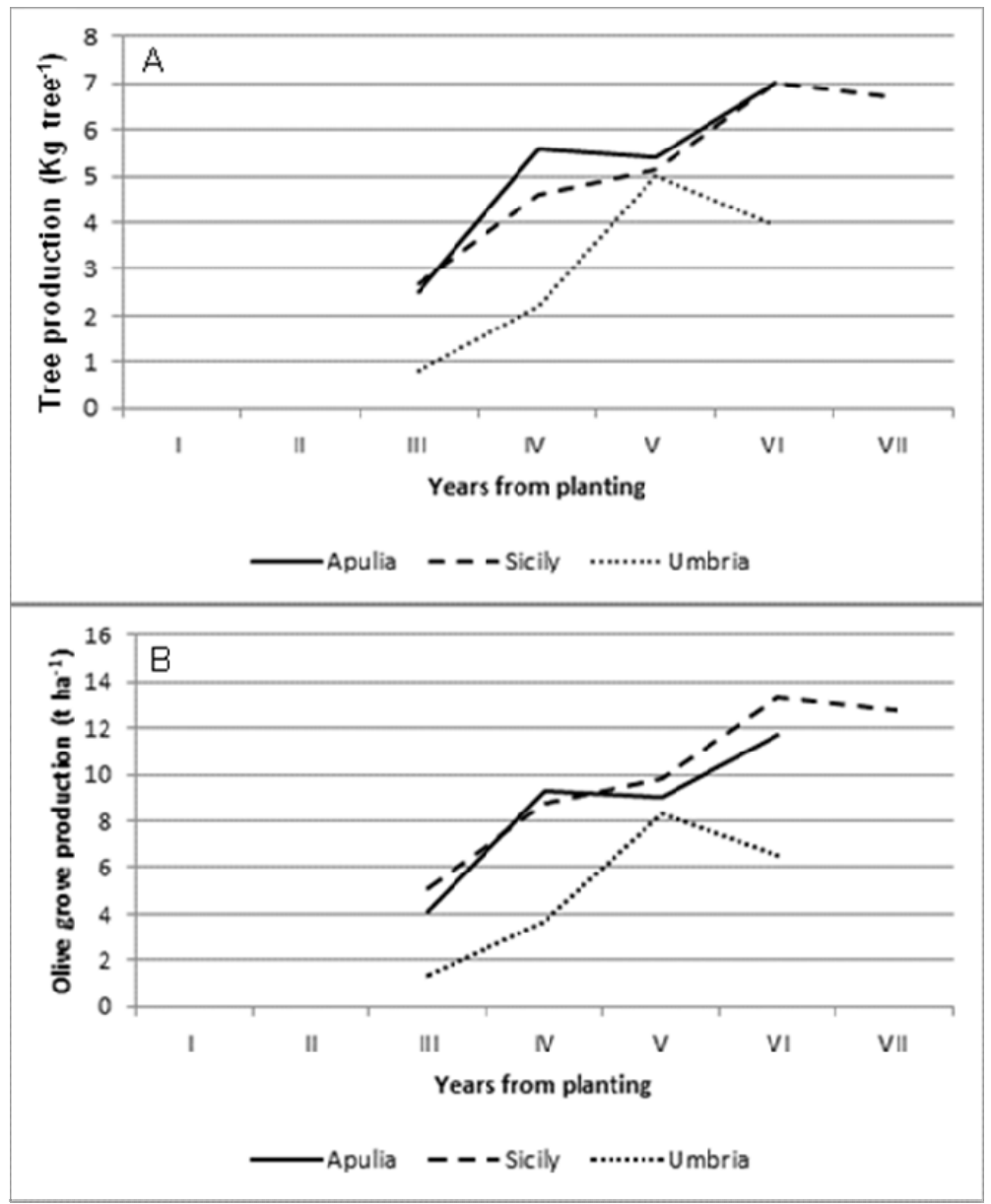

Fig. 1. Tree (A) and olive grove (B) production of 'Arbequina' in super high-density planting systems, in three different olive growing areas in Italy. 


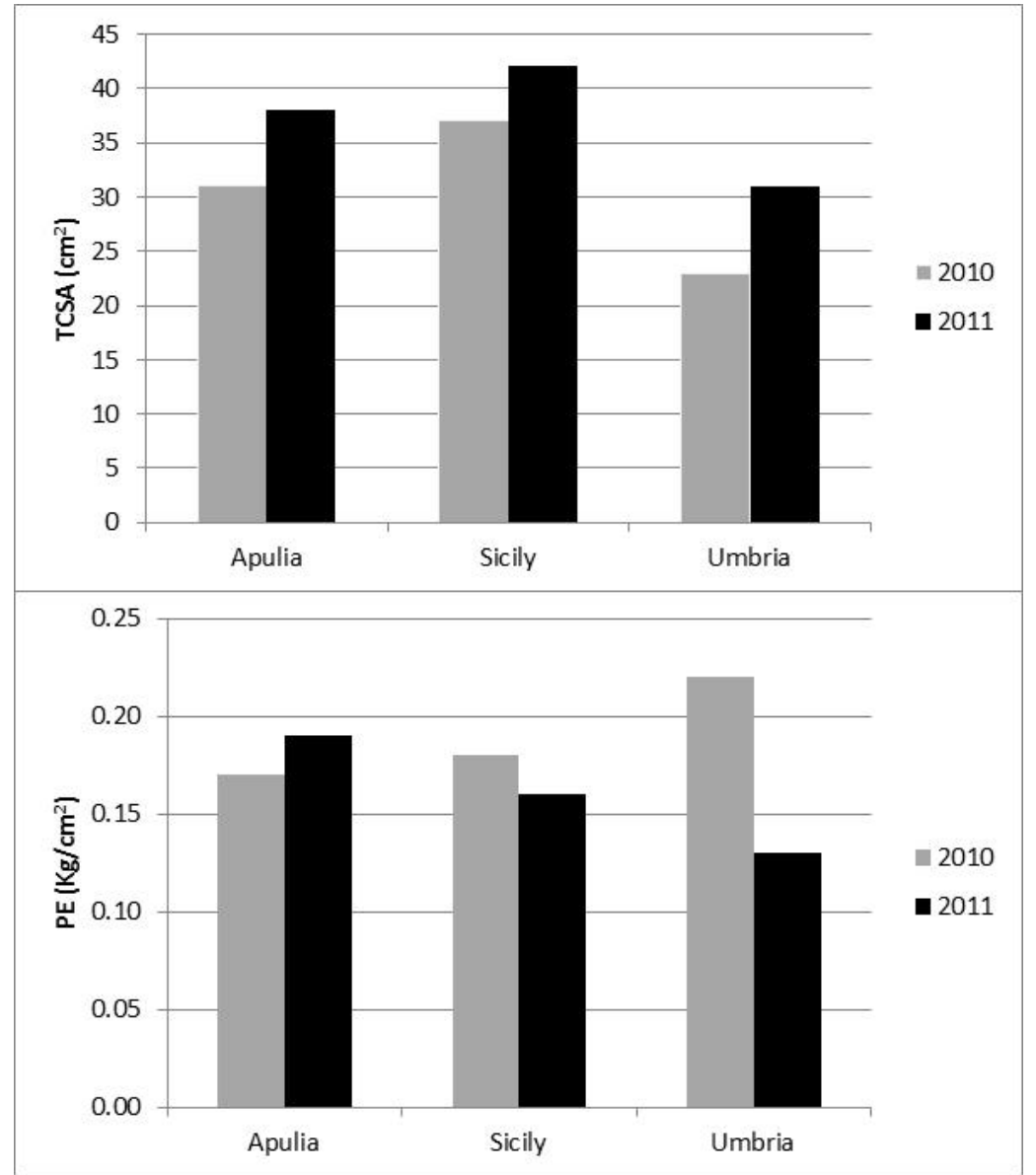

Fig. 2. Trunk cross sectional area (TCSA) and production efficiency (PE) of 'Arbequina' trees in super high-density planting systems, in three different olive growing areas in Italy. 